\title{
Pengembangan Media Pembelajaran Berbasis Role Playing Game (RPG) untuk Siswa Kelas X SMK Negeri 3 Yogyakarta
}

\author{
I Putu Yana Swadyaya ${ }^{1}$, Fatchul Arifin ${ }^{2}$ \\ ${ }^{1,2}$ Program Studi Pendidikan Teknik Elektronika Fakultas Teknik Universitas Negeri Yogyakarta \\ E-mail: aji0swadyaya@gmail.com
}

\begin{abstract}
The purpose of this study is to develop a game like learning media program about resistor's color code reading and simple resistor circuits made in $R P G$ Maker MV game engine for grade $X$ vocational school student. The developed learning media includes: learning media program, student workbook, and a complementary module book. The method of research and development is used in this study. Descriptive analysis was used on the feasibility analysis of learning media. The assessment aspects consist of aspects of software engineering, aspects of learning design and aspects of visual communication. Result of experts and users test validation stated that the developed learning media is in the feasible category based on all validated and tested aspects. Even though the media is declared feasible, further study is needed regarding the application of the RPG approach to engineering material. The RPG approach to learning media is expected not to cause new problems in the process of student understanding.
\end{abstract}

Keywords: media, resistor, circuit, RPG Maker, game

\begin{abstract}
ABSTRAK
Penelitian ini bertujuan untuk mengembangkan program media pembelajaran berbentuk game tentang pembacaan kode gelang resistor dan rangkaian resistor sederhana dengan game engine RPG Maker MV untuk siswa SMK kelas X. Media pembelajaran yang dikembangkan terdiri dari: program media pembelajaran, lembar kerja siswa, dan sebuah modul pelengkap. Penelitian dilaksanakan menggunakan metode penelitian dan pengembangan (research and development). Analisa kelayakan media pembelajaran menggunakan analisa deskriptif. Hasil validasi ahli dan uji pengguna menunjukkan media pembelajaran yang dikembangkan berada dalam kategori layak berdasarkan seluruh aspek yang divalidasi dan diujikan. Aspek penilaian terdiri atas aspek rekayasa perangkat lunak, desain pembelajaran dan komunikasi visual. Meskipun media dinyatakan layak, akan tetapi diperlukan pengkajian lebih lanjut mengenai penerapan pendekatan RPG untuk materi teknik. Pendekatan RPG pada media pembelajaran diharapkan tidak menimbulkan permasalahan baru dalam proses pemahaman siswa.
\end{abstract}

Kata kunci: media, resistor, rangkaian, RPG Maker, game

\section{PENDAHULUAN}

Pengembangan alat atau lingkungan yang mendukung kreativitas dalam pembelajaran dapat diupayakan salah satunya melalui penyajian konten dengan multimedia interaktif [1]. Hal tersebut memperkaya khasanah pendidikan. Pendidikan adalah jalan bagi manusia untuk mengembangkan kemampuan dan kepribadian yang dimilikinya, oleh karenanya tidak salah jika pendidikan dikatakan sebagai sebuah keharusan bagi manusia [2]. Usaha diperlukan kemampuan dan kepribadian yang dimiliki dapat berkembang. Melalui jalur pendidikan, baik formal maupun non-formal dapat dilakukan bermacam usaha untuk memperbaiki sumber daya manusia agar berubah menjadi lebih baik.

Sekolah Menengah Kejuruan (SMK) merupakan lembaga pendidikan vokasi dengan tujuan mengasah dan mengembangkan kemampuan peserta didik secara spesifik pada 
kejuruan tertentu. Teknik Elektronika merupakan salah satu program keahlian di SMK. Ilmu yang dipelajari dalam kejuruan teknik elektronika adalah ilmu- ilmu listrik arus rendah. Ilmu ini setelah dipelajari dapat digunakan untuk merawat, mendiagnosis, dan mereparasi berbagai macam peralatan elektronika. Siswa Teknik Elektronika mempelajari mata pelajaran Teknik Listrik. Dalam mata pelajaran ini dibahas berbagai sifat arus listrik dalam rangkaian elektronika. Ilmu yang diperoleh dalam mata pelajaran ini dapat digunakan untuk melakukan diagnosis terhadap kondisi alat elektronika melalui beberapa perhitungan serta pengukuran komponen di suatu rangkaian elektronika.

Mata pelajaran ini memiliki banyak konsep dan rumus perhitungan, sehingga kebanyakan siswa merasa kesulitan untuk memahami materi dari mata pelajaran ini. Guru pada umumnya hanya memberikan materi melalui ceramah dan menggunakan media buku yang kurang menarik bagi siswa. Pemahaman konsep dan teori pada mata pelajaran ini bisa didapatkan dari penjelasan guru di sekolah, namun masih perlu dipertajam oleh siswa itu sendiri melalui review pelajaran dan latihan soal di rumah. Siswa pada umumnya kurang berminat untuk mereview pelajaran dan mengerjakan latihan soal di rumah. Hal ini dikarenakan siswa kurang dapat memahami pelajaran yang ia dapat di sekolah. Satu kompetensi dasar yang ada di dalam mata pelajaran ini adalah: memahami fungsi rangkaian resistor rangkaian kelistrikan. Mata pelajaran ini memaparkan cara mengetahui nilai hambatan resistor dengan cara membaca kode warna gelang yang ada di fisik resistor dan beda nilai potensial dalam rangkaian listrik dengan beban resistor sederhana.

Tingkat pemahaman siswa terhadap materi teknik listrik dapat meningkat apabila siswa memiliki ketertarikan terhadap materi tersebut. Media dan metode pembelajaran yang menarik akan meningkatkan ketertarikan dan minat siswa terhadap materi yang dipelajari. Role Playing Game (RPG) dapat dijadikan media pembelajaran pada mata pelajaran. Game ini akan menyajikan petualangan yang berisi tentang konsep dan teori dasar mata pelajaran teknik listrik. Game juga digemari oleh para remaja dan dapat dimainkan di waktu senggang. RPG merupakan permainan di mana seseorang berperan sebagai karakter dalam game itu. Game jenis ini berjalan dengan mengikuti sebuah alur cerita tertentu yang telah ditentukan. RPG menyajikan perkembangan alur cerita melalui narasinya dan aksi dari karakternya. Perkembangan alur cerita yang menarik membuat pemain dapat memahami apa yang terjadi di sekitar karakter game. Hal tersebut membuat suatu pengalaman yang membekas di ingatan pemain. RPG dapat dikembangkan menjadi sebuah media pembelajaran. Alur cerita game dapat dimodifikasi dengan materi-materi dari pelajaran, dan konsep serta rumusan dari mata pelajaran teknik listrik. Konsep serta rumusan tersebut dapat diubah menjadi beberapa senjata atau kemampuan karakter. RPG telah banyak diimplementasikan pada pembelajaran [3]-[5]. Game ini akan menuntut siswa untuk memahami konsep pembacaan gelang warna resistor dan rumus- rumus hukum tegangan sederhana. Terkait peningkatan pemahaman konsep, aspek tampilan dan teknis perlu diperhatikan [6]. Game ini diharapkan dapat meningkatkan pemahaman siswa SMK program keahlian Teknik Elektronika terhadap materi teknik listrik.

\section{METODE}

Peneitian ini menggunakan metode Penelitian dan Pengembangan (Research and Development). Metode penelitian ini merupakan suatu metode yang dipergunakan dalam mengembangkan dan menghasilkan suatu produk tertentu, untuk kemudian menguji seberapa efektif produk tersebut [7]. Borg \& Gall menyatakan bahwa penelitian dan pengembangan dalam industri merupakan tulang punggung suatu industri dalam proses untuk memproduksi berbagai variasi produk baru yang diperlukan oleh pasar. Penelitian ini dilaksanakan selama 1 bulan, yaitu selama pertengahan bulan April-Mei 2019. Tempat 
penelitian pengembangan media Game RPG adalah Jurusan Pendidikan Teknik Elektronika Universitas Negeri Yogyakarta dan uji coba media pembelajran dilakukan siswa kelas $\mathrm{X}$ SMK N 3 Yogyakarta Jurusan Elektronika di labolatorium Komputer selama jam pembelajaran praktik. Subjek penelitian ini adalah media pendidikan teknik listrik kompetensi dasar memahami fungsi rangkaian resistor rangkaian kelistrikan berbasis RPG. Objek penelitian ini adalah siswa SMK kelas X Jurusan Elektronika. Prosedur penelitian merupakan modifikasi dari Sugiyono [7] sesuai dengan kebutuhan dalam penelitian ini. Prosedur penelitian ini dapat disajikan pada Gambar 1.

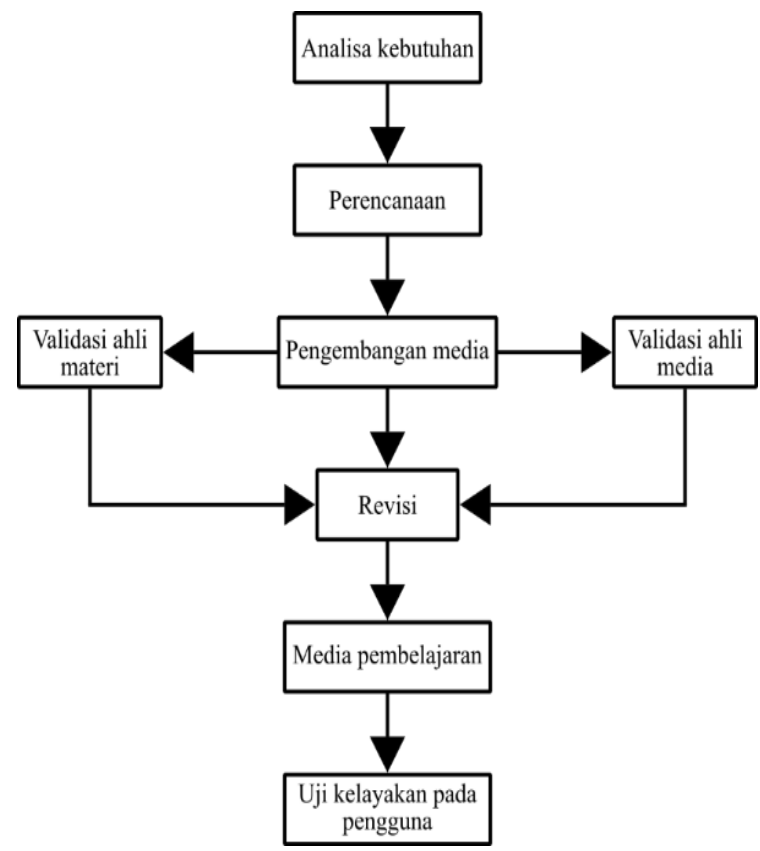

Gambar 1. Prosedur penelitian

Analisis kebutuhan dilakukan menggunakan metode wawancara dan observasi kepada siswa kelas X SMK Program Keahlian Elektronika mengenai hambatan yang dialami dalam mempelajari materi pada kompetensi dasar memahami fungsi rangkaian resistor rangkaian kelistrikan. Hasil analisis yang diperoleh kemudian dijadikan acuan dalam merencanakan produk awal. Dalam proses perencanaan ini ditentukan tentang materi dan gameplay yang akan diterapkan dalam game. Pengembangan game terdiri atas: perencanaan cerita, peta ( $m a p$ ) permainan, karakter-karakter yang akan dimainkan, musuh-musuh yang akan dilawan, puzzle-puzzle yang mencakup materi pembelajaran. Tahapan selanjutnya adalah validasi ahli materi dan media, dimana produk penelitian berupa media pembelajaran berbasis RPG dinilaikan kepada ahli materi dan ahli media pembelajaran. Melakukan revisi/ perbaikan pada media pembelajaran sesuai dengan yang masukan dan saran para ahli. Media pembelajaran yang setelah melalui proses validasi dan revisi diujicobakan kepada siswa SMK kelas $\mathrm{X}$ program keahlian Teknik Elektronika. Tahapan terakhir adalah siswa SMK kelas $\mathrm{X}$ program keahlian Teknik Elektronika menilai media pembelajaran melalui angket.

Tabel 1. Kisi-kisi kelayakan instrumen ahli media

No Aspek yang Dinilai $\quad \begin{gathered}\text { Jumlah } \\ \text { Butir }\end{gathered}$

Apek Rekayasa Perangkat Lunak

1. Reliabel (kehandalan program media) 2

2. Usabilitas (mudah digunakan dan 1 sederhana dalam pengoperasiannya)

3. Pemaketan program media pembelajaran 1 terpadu dan mudah dieksekusi

4. Dokumentasi program media pembelajaran yang lengkap meliputi: petunjuk instalasi (jelas, singkat, lengkap), trouble shooting (jelas, terstruktur, dan antisipatif), desain program (jelas, menggambarkan alur kerja program)

5. Reusable (sebagian atau seluruh program media pembelajaran dapat dimanfaatkan kembali untuk mengembangkan media pembelajaran lain)

Aspek Komunikasi Visual

6. Komunikatif; sesuai dengan pesan dan 1 dapat diterima/sejalan dengan keinginan sasaran

7. Kreatif dalam ide berikut penuangan 1 gagasan

8. Sederhana dan memikat 3

9. Audio (narasi, sound effect, backsound, 2 musik)

10. Visual (layout design, typography, 3 warna)

11. Media bergerak (animasi, movie) 2

12. Layout Interactive (ikon navigasi) 2

Total 
Instumen penelitian yaitu kelengkapan yang dipergunakan dalam proses pengumpulan data. Data kelayakan produk untuk penelitian ini berupa instrumen lembar penilaian kelayakan produk dari sisi ahli (ahli media dan materi pembelajaran) dan pengguna produk (siswa). Kisi-kisi untuk analisis instrumen uji kelayakan dikutip dan dimodifikasi dari Wahono [8]. Kisikisi dari instrumen uji kelayakan untuk ahli media pembelajaran ditampilkan dalam Tabel 1 . Kisi-kisi daru instrumen uji kelayakan untuk ahli materi ditampilkan dalam Tabel 2. Kisi-kisi instrumen uji kelayakan untuk pengguna (siswa) ditampilkan dalam Tabel 3.

Tabel 2. Kisi-kisi instrumen kelayakan ahli materi (Aspek Desain Pembelajaran)

\begin{tabular}{|c|c|c|}
\hline No & Aspek yang Dinilai & $\begin{array}{c}\text { Jumlah } \\
\text { Butir }\end{array}$ \\
\hline & $\begin{array}{l}\text { Kejelasan tujuan pembelajaran (rumusan, } \\
\text { realistis) }\end{array}$ & 1 \\
\hline & $\begin{array}{l}\text { Relevansi tujuan pembelajaran dengan } \\
\text { SK/KD/Kurikulum }\end{array}$ & 2 \\
\hline & $\begin{array}{l}\text { Cakupan dan kedalaman tujuan } \\
\text { pembelajaran }\end{array}$ & 2 \\
\hline & $\begin{array}{l}\text { Ketepatan penggunaan strategi } \\
\text { pembelajaran }\end{array}$ & 1 \\
\hline & Interaktivitas & 1 \\
\hline & Pemberian motivasi belajar & 1 \\
\hline & Kontekstualitas dan aktualitas & 2 \\
\hline & $\begin{array}{l}\text { Kelengkapan dan kualitas bahan bantuan } \\
\text { belajar }\end{array}$ & 2 \\
\hline & $\begin{array}{l}\text { Kesesuaian materi dengan tujuan } \\
\text { pembelajaran }\end{array}$ & 1 \\
\hline & Kedalaman materi & 1 \\
\hline & Kemudahan untuk dipahami & 2 \\
\hline & Sistematis, runtut, alur logika jelas & 2 \\
\hline & $\begin{array}{l}\text { Kejelasan uraian, pembahasan, contoh, } \\
\text { simulasi, Latihan }\end{array}$ & 2 \\
\hline & $\begin{array}{l}\text { Konsistensi evaluasi dengan tujuan } \\
\text { pembelajaran }\end{array}$ & 1 \\
\hline & Ketepatan dan ketetapan alat evaluasi & 1 \\
\hline \multirow{2}{*}{\multicolumn{2}{|c|}{$\begin{array}{l}\text { 16. Pemberian umpan balik terhadap hasil } \\
\text { evaluasi } \\
\text { Total }\end{array}$}} & 1 \\
\hline & & 23 \\
\hline
\end{tabular}

Upaya yang dilakukan dalam pelaksanaan pengumpulan data subjek dan objek penelitian disebut sebagai metode pengumpulan data. Langkah awal yang dilakukan adalah menganalisis kebutuhan di lapangan menggunakan observasi. Langkah selanjutnya adalah membuat instrumen tentang seberapa layak produk yang dikembangkan. Pengujian tingkat kelayakan produk dilakukan oleh ahli media dan ahli materi. Setelah mendapatkan saran dari para ahli, maka produk dapat direvisi sesuai yang diharapkan para ahli. Setelah melalui proses revisi, produk dinilai kelayakannya kepada siswa sebagai pengguna produk.

Tabel 3. Kisi-kisi kelayakan instrumen pengguna (siswa)

\begin{tabular}{llc}
\hline No. & Aspek yang Dinilai & $\begin{array}{c}\text { Jumlah } \\
\text { Butir }\end{array}$ \\
\hline
\end{tabular}

Apek Rekayasa Perangkat Lunak

1. Reliable (kehandalan program media) 2

2. Usabilitas (mudah digunakan dan 1 sederhana dalam pengoperasiannya)

3. Dokumentasi program media pembelajaran yang lengkap meliputi: petunjuk instalasi (jelas, singkat, lengkap), trouble shooting (jelas, terstruktur, dan antisipatif), desain program (jelas, menggambarkan alur kerja program)

Aspek Desain Pembelajaran

4. Pemberian motivasi belajar 1

5. Kelengkapan dan kualitas bahan 2 bantuan belajar

6. Kemudahan untuk dipahami 1

7. Sistematis, runtut, alur logika jelas 2

8. Kejelasan uraian, pembahasan, contoh, 2 simulasi,

Latihan

Aspek Komunikasi Visual

9. Komunikatif; sesuai dengan pesan dan 1 dapat diterima/sejalan dengan keinginan sasaran

10. Sederhana dan memikat 3

11. Audio (narasi, sound effect, 1 backsound,musik)

12. Visual (layout design, typography, 1 warna)

13. Media bergerak (animasi, movie) 1

14. Layout Interactive (ikon navigasi) 2

Metode deskriptif dan parametris digunakan untuk mengalisa data dalam penelitian ini. Analisis deskriptif adalah analisis yang dilakukan melalui data sampel atau populasi apa adanya, tanpa melakukan analisis dan membuat kesimpulan yang berlaku secara umum untuk mendeskripsikan atau memberi gambaran terhadap objek yang diteliti [7]. 
Statistik parametris digunakan untuk menguji parameter populasi melalui statistik atau menguji ukuran populasi data melalui sampel [7].

Analisis kelayakan Media Pembelajaran Fungsi Rangkaian Resistor dan Implementasinya Berbasis RPG menggunakan analisis deskriptif yaitu dengan menentukan skor ideal. Analisa deskripstif ini digunakan untuk menghitung skor yang didapat atas evaluasi para ahli dan pengguna. Skor ideal ditetapkan melalui asumsi bahwa setiap responden menjawab pertanyaan dengan skor tertinggi untuk setiap pertanyaan. Kemudian untuk menjawab rumusan masalah, dilakukan dengan cara membagi jumlah skor hasil dengan skor ideal. Analisis kelayakan dapat digambarkan dengan persamaan 1. Hasil perhitungan disajikan dalam bentuk persentase yang kemudian dideskripsikan dan mengambil kesimpulan tentang masing-masing indikator berdasarkan kriteria pada Tabel 4.

$$
\text { Kelayakan media }=\frac{\text { skor yang diperoleh }}{\text { skor ideal }} \times 100 \%
$$

(persamaan 1)

Tabel 4. Kriteria penilaian kelayakan media pembelajaran berbasis RPG

\begin{tabular}{ccc}
\hline $\begin{array}{c}\text { Presentase yang } \\
\text { Diperoleh }\end{array}$ & Skor & Interpretasi \\
\hline$>80 \%$ & 5 & Sangat Layak \\
$61-80 \%$ & 4 & Layak \\
$41-60 \%$ & 3 & Cukup Layak \\
$21-40 \%$ & 2 & Kurang Layak \\
$<21 \%$ & 1 & Tidak Layak \\
\hline
\end{tabular}

Analisa parametris pada penelitian ini digunakan untuk memeriksa tingkat validitas dan realibilitas intstrumen evaluasi yang akan digunakan oleh penguna (siswa). Rumus Korelasi Pearson digunakan untuk menghitung validitas instrumen. Hasil dari perhitungan ini kemudian akan dibandingkan kembali dengan nilai rtabel yang nilainya ditentukan oleh banyaknya jumlah sampel yang digunakan. Poin/item tersebut dinyatakan valid apabila nilainya sama atau lebih besar dibandingkan nilai rtabel-nya. Nilai realibilitas instrumen dihitung menggunakan rumus alpha. Instrumen dianggap valid apabila hasil perhitungan rumus alpha memiliki nilai di atas 0,60 .

\section{HASIL DAN PEMBAHASAN}

Berdasarkan hasil wawancara dan observasi, ketertarikan siswa terhadap materi ini tidak kurang. Beberapa siswa merasa bosan dengan materi ini. Kesulitan siswa dalam mempelajari materi ini bervariasi antara pemahaman arti gelang warna resistor, pemahaman rangkaian resistor sederhana, atau keduanya. Guru narasumber sendiri mengutarakan cukup kesulitan menemukan media pembelajaran yang inovatif untuk menyampaikan materi. Narasumber juga mendukung pengembangan sebuah media pembelajran berbentuk permainan video dengan fokus ke materi pembelajaran. Penelitian ini memiliki tujuan untuk mengembangkan sebuah media pembelajaran berupa permainan game video dengan genre role playing game (RPG) untuk menarik minat dan motivasi siswa, serta mengetahui seberapa tinggi tingkat kelayakan dari media pembelajaran yang dikembangkan.

Dalam pengembangan media pembelajaran ini beberapa jenis perangkat lunak digunakan untuk membuat dan memodifikasi pemrograman serta aset-aset yang ada di dalamnya. Beberapa program yang digunakan dalam pengembangan media pembelajaran ini adalah: (1) RPG Maker MV. Perangkat lunak utama yang digunakan untuk membuat media peembelajaran ini. RPG Maker MV merupakan sebuah game engine yang dikhususkan untuk mengembangkan permainan video bergenre role playing game (RPG) dua dimensi dengan tampilan top-down. Engine ini adalah model teranyar yang dikeluarkan pada tahun 2015 . Gambar 2 berikut menampilkan tangkapan layar menu utama dari game engine ini; (2) Aseprite. Perangkat lunak yang dikhususkan untuk membuat aset media pembelajaran berupa sprite dan icon dalam bentuk pixel art. Kebutuhan aset yang akan digunakan dalam media pembelajaran ini tidak tercakup oleh aset bawaan dari game 
engine yang digunakan, oleh karena itu peneliti harus membuat aset yang diperlukan secara mandiri. Menu utama dari program ini ditampilkan pada Gambar 3; (3) GIMP (GNU Image Manipulation Program). Sebuah perangkat lunak untuk membuat, mengolah, dan memanipulasi gambar (picture, image). Selain membuat secara mandiri, aset-aset yang diperlukan juga dapat diperoleh melalui forum dan situs pengembang permainan video di internet. Aset-aset tersebut kemudian harus dimodifikasi lagi agar sesuai dengan kebutuhan dan spesifikasi yang diperlukan dalam media pembelajaran. Tampilan jendela utama pada program GIMP ditampilkan pada Gambar 4; (5) Medibang Paint Pro. Perangkat lunak untuk membuat ilustrasi digital 2 dimensi. Peneliti menggunakan perangkat lunak ini untuk mendesain sketsa kasar yang seterusnya akan diberikan kepada ilustrator yang lebih berpengalaman untuk membuat ilustrasi para karakter dan musuh-musuh yang dilawan dalam media pembelajaran. Gambar 5 berikut menampilkan tangkapan layar menu utama dari program Medibang Paint Pro; dan (6) Audacity, sebuah perangkat lunak untuk memodifikasi aset permainan berupa berkas suara atau musik. Peneliti menggunakan perangkat lunak ini untuk melakukan modifikasi ringan pada aset suara dan musik agar dapat digunakan pada media pembelajaran. Tampilan utama dari program Audacity dapat dilihat pada Gambar 6.

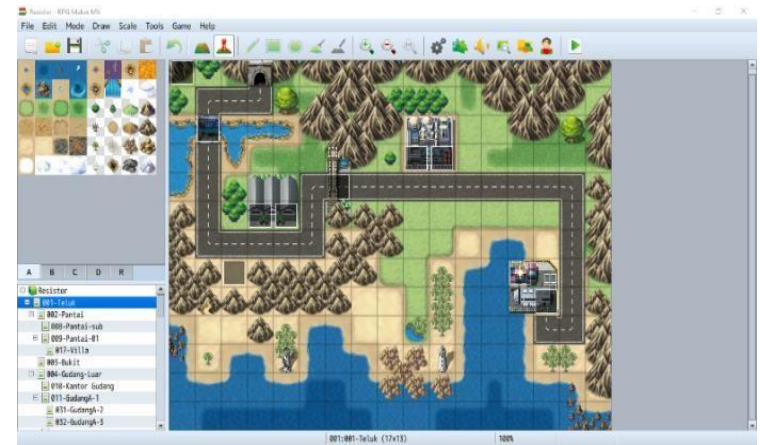

Gambar 2. Tampilan program RPG Maker MV

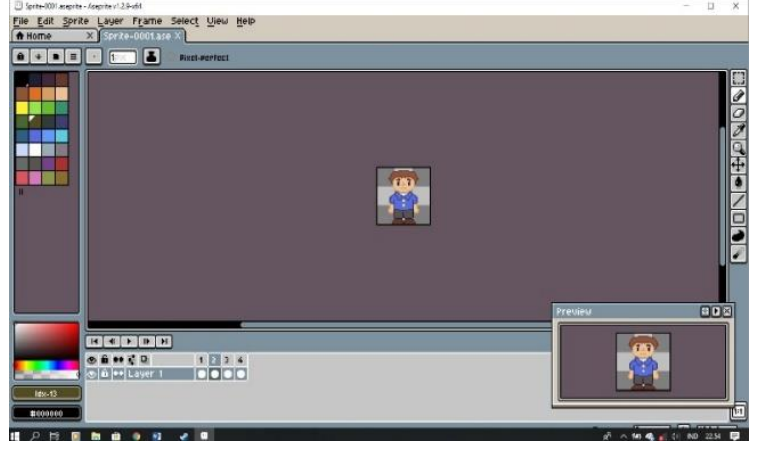

Gambar 3. Tampilan program Aseprite

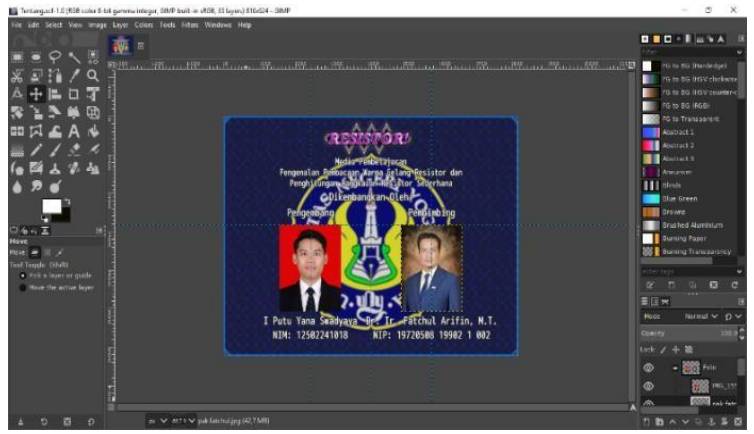

Gambar 4. Tampilan program GIMP

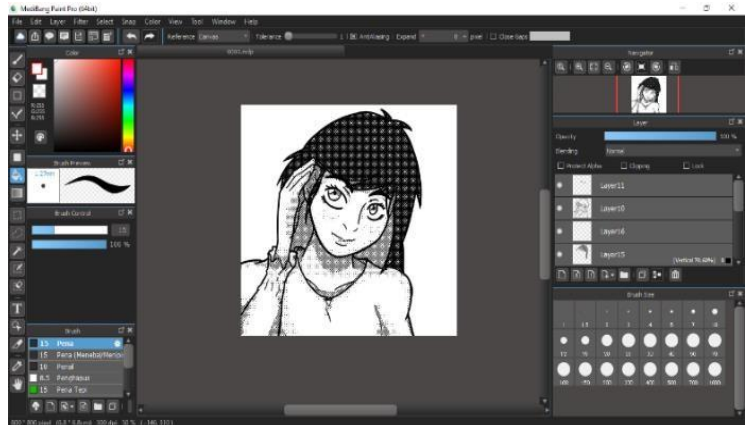

Gambar 5. Tampilan program Medibang Paint Pro

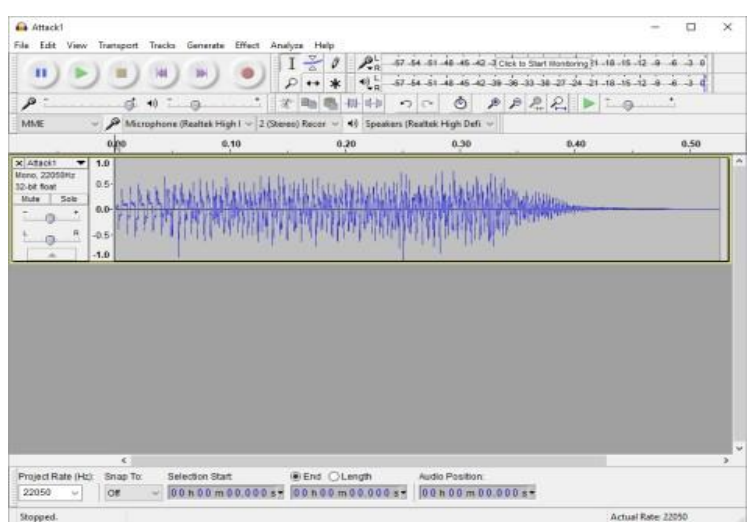

Gambar 6. Tampilan program Audacity 
Proses pengembangan media dimulai dengan penentuan materi. Materi yang dipergunakan dalam media pembelajaran adalah materi dasar yang memiliki kaitan dengan pembacaan kode warna gelang resistor dan penghitungan nilai resistor dalam rangkaian sederhana. Materi-materi tersebut adalah: (1) menghafal nilai-nilai gelang warna resistor; (2) menghitung nilai resistor total pada rangkaian seri; (3) menghitung nilai resistor total pada rangkaian paralel; dan (4) menghitung nilai resistor total pada rangkaian seri-paralel. Setelah materi ditentukan, langkah berikutnya adalah perancangan soal. Soal dalam media pembelajaran dibuat menyerupai papan $\mathrm{PCB}$ (Printed Circuit Board) dengan satu rangkaian resistor. Rangkaian- rangkaian ini tersusun seri, paralel, atau campuran tergantung dari area peta dalam media pembelajaran. Setiap rangkaian memiliki satu resistor yang rusak/hilang, untuk menyelesaikannya siswa harus menghitung dan memasang nilai resistor yang tepat. Setiap papan PCB memberikan informasi berupa nilai tegangan total dan nilai arus total. Resistor yang terpasang, selain resistor yang hilang menampilkan nilainya dengan gelang warna, bukan nilai numeral. Setelah mendapat nilai resistor yang diperlukan, siswa harus "membuat" resistor yang diperlukan. Resistor dibuat melalui menu sintesis dengan bahan yang didapatkan melalui pertarungan di peta media pembelajaran.

Tahapan ketiga adalah perancangan cerita dan peta media pembelajaran. Mendesain titiktitik utama cerita karakter media pembelajaran. Termasuk di dalamnya: dialog awal/prolog, dialog akhir/epilog, dialog tentang materi, dan dialog tentang beberapa fitur game. Peta dasar (tanpa pernak-pernik dan gambar penghias) dibuat. Peta- peta yang dibuat pertama adalah peta yang akan dilengkapi dengan soal/puzzle resistor. Tahapan keempat adalah perancangan gameplay media pembelajaran. Perancangan berbagai barang yang dan perlengkapan yang akan digunakan oleh siswa dalam media pembelajaran, musuh yang akan dilawan, serta event umum yang akan digunakan. Tangkapan layar tentang beberapa bagian database pada game engine RPG maker MV dapat dilihat pada Gambar 7, Gambar 8, dan Gambar 9.

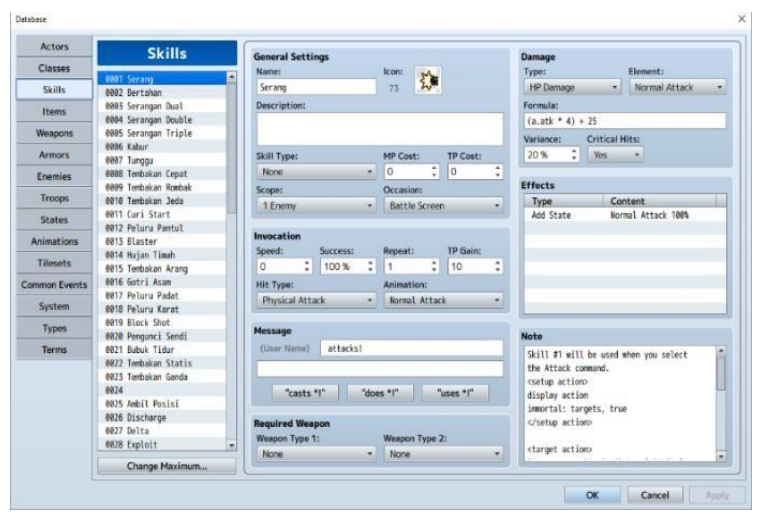

Gambar 7. Database skill RPG Maker MV

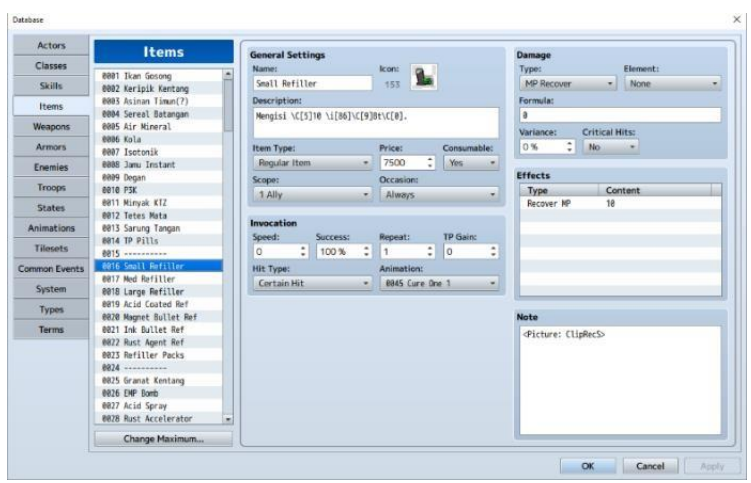

Gambar 8. Database item RPG Maker MV

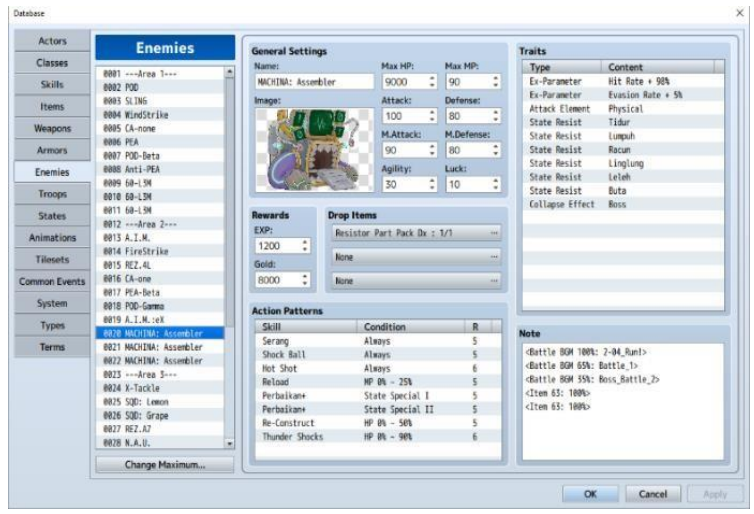

Gambar 9. Database enemy RPG Maker MV

Tahap kelima adalah Eventing Media Pembelajaran. Event adalah berbagai macam "kejadian" dalam media permainan yang dapat dipicu oleh pemain, baik dengan bergerak ke lokasi tertentu, menekan tombol, dan/atau berpindah peta. Event ini digunakan untuk menampilkan dialog, memberi akses ke peta yang terkunci, dan sebagainya. Setelah semua aset yang diperlukan lengkap, dilanjutkan 
dengan mendesain event yang diperlukan pada setiap peta. Event tersebut antara lain, di mana musuh akan muncul, jenis resistor yang diperlukan di pintu soal/puzzle, dan dialog antar karakter. Pada Gambar 10, Gambar 11, dan Gambar 12 dapat dilihat sekilas mengenai jendela-jendela yang diakses pada proses eventing.

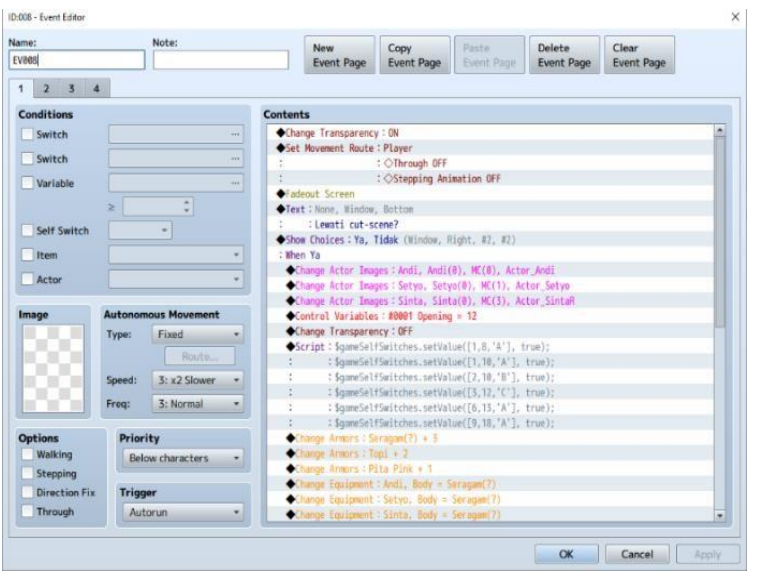

Gambar 10. Jendela event editor RPG Maker MV

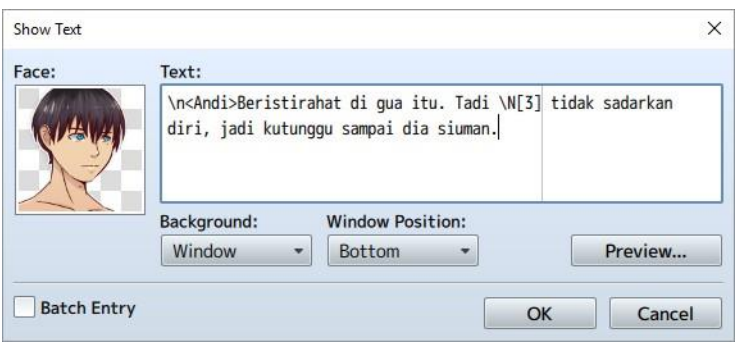

Gambar 11. Jendela text editor RPG Maker MV

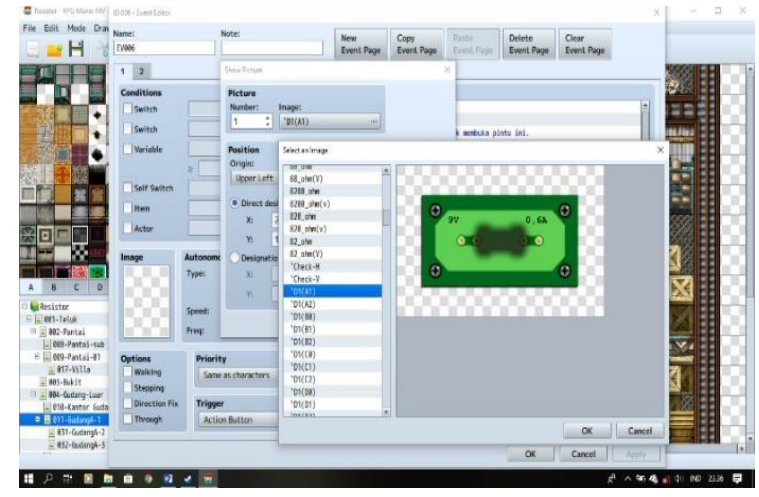

Gambar 12. Contoh editing event soal/puzzle pada RPG Maker MV

Tahap keenam adalah beta testing dan perbaikan media pembelajaran. Setelah semua aset dan event dalam media pembelajaran tersusun, media pembelajaran diberikan kepada beberapa beta tester untuk menemukan masalah masalah yang ada dalam media permainan. Proses testing ini berjalan selama 2 sampai 7 hari karena ukuran media pembelajaran yang cukup kecil. Setelah pengujian selesai, dan tester membuat daftar masalah dalam media, proses selanjutnya adalah memperbaiki masalahmasalah tersebut. Proses beta testing diulang dua kali dalam pengembangan media ini. Setelah masalah-masalah yang ditemukan pada proses testing sebelumnya diperbaiki, dilanjutkan dengan proses pemeriksaan akhir oleh peneliti dan para beta-tester. Tidak ditemukan adanya masalah pada beta dan media siap untuk divalidasi.

Terdapat tujuh puluh dua (72) poin yang diperiksa dalam unjuk kerja media pembelajaran ini. Tiga (3) poin dalam kategori ukuran dan penggunaan memori, semua hasil tes baik. Enam (6) poin dalam kategori kontrol, semua hasil tes baik. Tiga puluh delapan (38) poin dalam kategori menu, tiga puluh tujuh (37) hasil tes baik, dan satu (1) kurang baik. Sembilan belas (19) poin dalam kategori fitur, semua hasi tes baik. Enam (6) poin dalam kategori pertarungan, semua hasil tes baik. Terkait adanya penilaian kurang baik pada kategori menu, maka hal tersebut perlu mendapatkan perbaikan.

Proses validasi media pembelajaran dilakukan oleh empat (4) orang ahli. Satu ahli materi dan satu ahli media dari Universitas Negeri Yogyakarta, serta satu ahli materi dan satu ahli media dari SMK Negeri 3 Yogyakarta. Instrumen evaluasi untuk Ahli Materi hanya mencakup aspek Desain Pembelajaran. Ahli Materi I memberikan nilai "Sangat Layak" sejumlah lima belas (15) nomor, dan delapan (8) nomor bernilai "Layak", dari total 23 nomor pada instrumen evaluasi. Skor total yang didapat dari penilaian Ahli Materi I adalah seratus tujuh (107) dari skor maksimal seratus lima belas (115), rerata skor sebesar 4,65, atau senilai $93,04 \%$ dari skor maksimal. Skor yang diberikan oleh Ahli Materi I menunjukkan media ini masuk ke dalam kategori "Sangat Layak". Ahli Materi II memberikan nilai "Layak" sejumlah empat belas (14) nomor, dan sembilan 
(9) nomor bernilai "Cukup Layak", dari total 23 nomor pada instrumen evaluasi. Skor total yang didapat dari penilaian Ahli Materi I adalah seratus tujuh (83) dari skor maksimal seratus lima belas (115), rerata skor sebesar 3,61, atau senilai $72,17 \%$ dari skor maksimal. Skor yang diberikan oleh Ahli Materi II menunjukkan media ini masuk ke dalam kategori "Layak". Gambar 13 menunjukkan hasil validasi ahli materi.

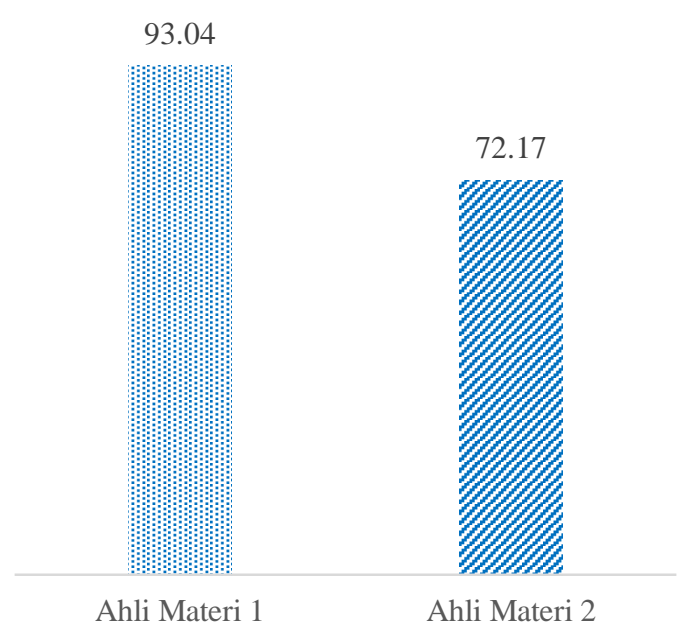

Gambar 13. Validasi ahli materi

Ahli Media I memberikan nilai "Sangat Layak" sejumlah satu (1) nomor dan lima (5) nomor bernilai "Layak", dari total enam (6) nomor pada aspek Rekayasa Perangkat Lunak di instrumen evaluasi. Nilai aspek Rekayasa Perangkat Lunak dari Ahli Media I adalah sebesar dua puluh lima (25) dari skor maksimal tiga puluh (30), rerata skor sebesar 4,17, atau senilai 83,3\%. Nilai yang diberikan Ahli Media I menunjukkan aspek Rekayasa Perangkat Lunak pada media pembelajaran ini berada pada kategori "Sangat Layak". Skor aspek Komunikasi Visual diberikan "Sangat Layak" sejumlah tujuh (7) nomor dan tujuh (7) nomor bernilai "Layak", dari total empat belas (14) nomor. Nilai aspek Komunkasi Visual dari Ahli Media I adalah sebesar enam puluh tiga (63) dari skor maksimal tujuh puluh (70), rerata skor sebesar 4,5, atau senilai 90\%. Nilai yang diberikan Ahli Media I menunjukkan aspek Komunikasi Visual pada media pembelajaran ini berada pada kategori "Sangat Layak".
Ahli Media II memberikan nilai "Sangat Layak" sejumlah tiga (3) nomor dan tiga (3) nomor bernilai "Layak", dari total enam (6) nomor pada aspek Rekayasa Perangkat Lunak di instrumen evaluasi. Nilai aspek Rekayasa Perangkat Lunak dari Ahli Media II adalah sebesar dua puluh tujuh (27) dari skor maksimal tiga puluh (30), rerata skor sebesar 4,5, atau senilai 90\%. Nilai yang diberikan Ahli Media II menunjukkan aspek Rekayasa Perangkat Lunak pada media pembelajaran ini berada pada kategori sangat layak. Skor aspek Komunikasi Visual diberikan "Sangat Layak" sejumlah enam (6) nomor dan delapan (8) nomor bernilai "Layak", dari total empat belas (14) nomor. Nilai aspek Komunkasi Visual dari Ahli Media II adalah sebesar enam puluh dua (62) dari skor maksimal tujuh puluh (70), rerata skor sebesar 4,43 , atau senilai $88,57 \%$. Nilai yang diberikan Ahli Media II menunjukkan aspek Komunikasi Visual pada media pembelajaran ini berada pada kategori "Sangat Layak". Gambar 14 menunjukkan hasil ahli media.

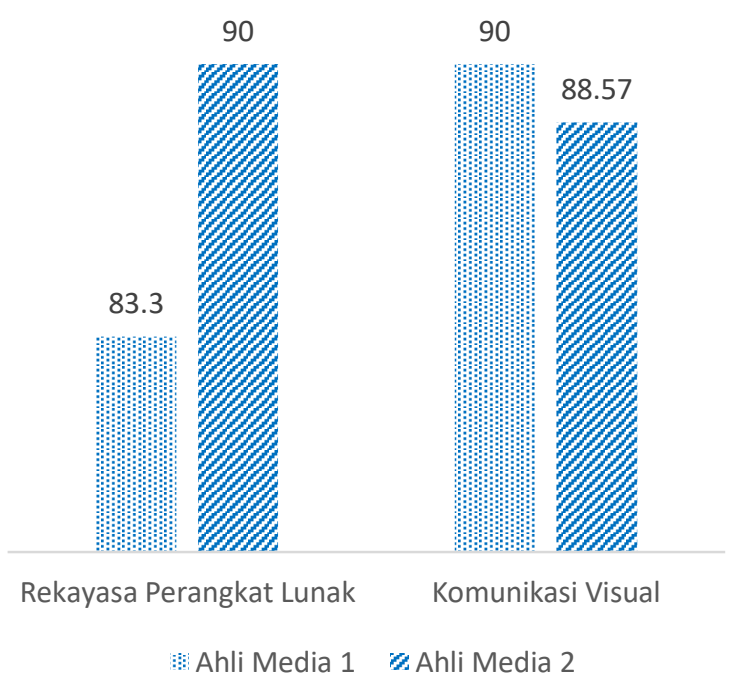

Gambar 14. Validasi ahli media

Pengukuran validitas dan realibilitas instrumen evaluasi siswa dilakukan pada tanggal 23 April 2019 dengan partisipan sebanyak tiga puluh satu (31) siswa kelas X di SMK Negeri 3 Yogyakarta. Media pembelajaran yang diujikan pada uji coba pertama adalah media stabil versi 
1.0.0 pre revisi. Dari tiga puluh satu (31) partisipan, diambil sebanyak dua belas (12) sampel. Data sampel ujicoba ini digunakan sebagai patokan untuk menghitung validitas, dan reliabilitas instrumen evaluasi siswa. Data nilai validitas dirangkum dalam Tabel 5 .

Tabel 5. Validitas instrumen pengguna

\begin{tabular}{rcc}
\hline No. & Korelasi Pearson & Keterangan \\
\hline 1 & $-0,213$ & Invalid \\
2 & 0,642 & Valid \\
3 & 0,609 & Valid \\
4 & 0,846 & Valid \\
5 & 0,663 & Valid \\
6 & 0,841 & Valid \\
7 & 0,844 & Valid \\
8 & 0,821 & Valid \\
9 & 0,812 & Valid \\
10 & 0,745 & Valid \\
11 & 0,803 & Valid \\
12 & 0,583 & Valid \\
13 & 0,649 & Valid \\
14 & 0,659 & Valid \\
15 & 0,824 & Valid \\
16 & 0,042 & Invalid \\
17 & 0,381 & Invalid \\
18 & 0,645 & Valid \\
19 & 0,832 & Valid \\
20 & 0,674 & Valid \\
21 & 0,600 & Valid \\
\hline
\end{tabular}

Jumlah sampel sebanyak dua belas (12) orang, dengan menggunakan taraf signifikansi senilai 5\%, maka nilai $\mathrm{r}$ Tabel yang digunakan sebesar 0,576. Hasil perbandingan nilai korelasi Pearson dengan nilai $r$ Tabel menunjukkan ada tiga (3) poin dari dua puluh satu (21) poin yang tidak valid. Satu (1) poin pada aspek Rekayasa Perangkat Lunak, dan dua (2) poin pada aspek Komunikasi Visual. Nilai perhitungan Cronbach's Alpha dari data yang dikumpulkan adalah 0,956 menunjukkan reliabilitas instrumen berada pada tingkatan sangat kuat.

Partisipan pada uji coba pada pengguna media pembelajaran sebanyak 27 siswa kelas $\mathrm{X}$ di SMK Negeri 3 Yogyakarta. Media pembelajaran yang diujikan pada uji coba pertama adalah media stabil versi 1.0.1 sesudah revisi. Data hasil uji coba ini digunakan untuk menghitung tingkat kelayakan media pembelajaran. Hasil uji penilaian pengguna disajikan pada Gambar 15. Penilaian aspek Rekayasa Perangkat Lunak dengan tiga (3) poin instrumen yang valid mendapatkan skor sebesar tiga ratus dua puluh satu (321) dari skor maksimal empat ratus lima (405), rerata skor tiga koma sembilan enam $(3,96)$, persentase kelayakan tujuh puluh sembilan koma tiga (79,3\%). Skor ini menunjukkan aspek Rekayasa Perangkat Lunak media pembelajaran ini berada pada kategori "Layak".

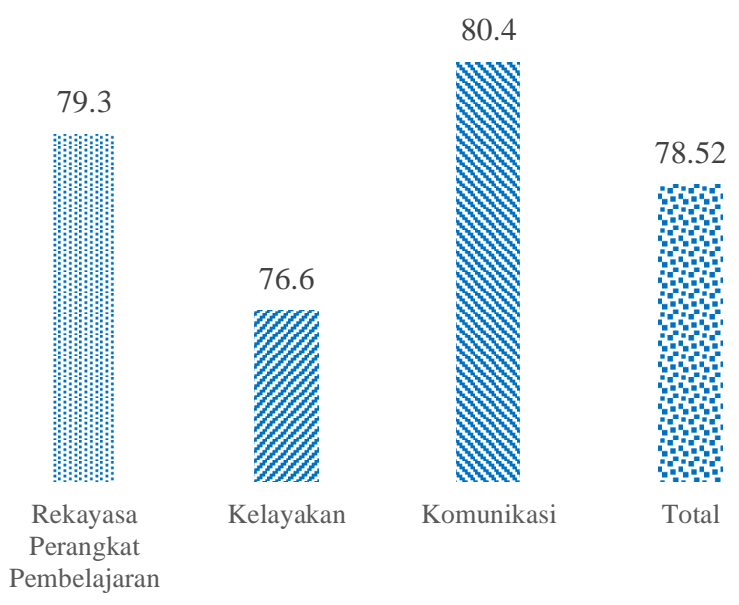

Gambar 15. Hasil penilaian pengguna (siswa)

Penilaian aspek Desain Pembelajaran dengan delapan (8) poin instrumen yang valid mendapatkan skor sebesar delapan ratus dua puluh tujuh (827) dari skor maksimal seribu delapan puluh (1080), rerata skor tiga koma delapan tiga $(3,83)$, persentase kelayakan tujuh puluh enam koma enam (76,6\%). Skor ini menunjukkan aspek Desain Pembelajaran media pembelajaran ini berada pada kategori "Layak". Penilaian aspek Komunikasi Visual dengan tujuh (7) poin instrumen yang valid mendapatkan skor sebesar tujuh ratus enam puluh (760) dari skor maksimal sembilan ratus empat puluh lima (945), rerata skor empat koma nol dua $(4,02)$, persentase kelayakan delapan puluh koma empat $(80,4 \%)$. Skor ini menunjukkan aspek Komunikasi Visual media pembelajaran ini berada pada kategori "Sangat Layak". Perhitungan keseluruhan data yang valid menunjukkan bahwa tingkat kelayakan 
dari media pembelajaran dinilai dari sisi siswa adalah sebesar 78,52\% dengan rerata skor 3,93, atau masuk ke kategori "Layak".

Hasil penilaian pengguna menunjukkan bahwa media telah layak digunakan. Meskipun demikian, media ini kurang cocok jika digunakan sebagai sarana pembelajaran di kelas. Media yang dikembangkan ini lebih baik digunakan sebagai sarana pelengkap pembelajaran yang digunakan pada waktu di luar jam pembelajaran sebagai bahan penguat pendalaman materi untuk siswa. Media ini juga dapat digunakan sebagai sarana pembelajaran untuk umum sebagai pengenalan awal tentang cara pembacaan resistor dan rangkaian sederhana. Salah satu pertimbangan adalah mengenai durasi waktu dan penggunaannya yang bersifat individu. Hal tersebut sejalan dengan penelitian yang menyatakan bahwa perlu diperhatikan terkait penggunaan RPG dalam pembelajaran adalah durasi waktu yang digunakan khususnya terkait pertimbangan motivasi sosial [9]. Pengembangan media pembelajaran video game dengan genre RPG eksplorasi perlu melakukan kajian lebih mendalam, terkait asumsi guru bahwa pendekatan menggunakan cara ini (RPG) kurang cocok sebagai media ajar mata pelajaran teknik. Sesuai dengan saran guru di SMK, untuk media pembelajaran yang ditargetkan pada mata pelajaran keteknikan sebuah simulasi atau trainer yang menyerupai alat/komponen aslinya akan lebih efektif.

Beberapa keterbatasan dalam penelitian antara lain: (1) materi yang dicakup oleh media pembelajaran terlalu singkat/ sedikit dibandingkan dengan lama waktu permainan; (2) genre RPG dengan gaya bermain eksplorasi kurang efektif sebagai cara penyajian media, dengan banyaknya siswa yang mengeluh kesulitan mengetahui arah perjalanan selanjutnya; (3) cerita dan penjelasan tentang materi dalam game dinilai "terlalu panjang dan membuat bosan" oleh siswa; dan (4) secara umum peneliti menyimpulkan bahwa media pembelajaran dengan model permainan video bergenre RPG eksplorasi kurang cocok sebagai media pembelajaran siswa di kelas.

\section{SIMPULAN}

Tiga aspek yang diujikan terdiri atas aspek rekayasa perangkat lunak, aspek desain pembelajaran dan aspek komunikasi visual. Berdasarkan hasil akhir dari proses penelitian dan pengembangan media pembelajaran berbasis RPG ini, peneliti menarik beberapa simpulan, yaitu: (1) pengembangan media pembelajaran terselesaikan dengan baik, dengan produk akhir berupa sebuah program media pembelajaran, sebuah lembar kerja siswa, dan sebuah modul pelengkap; (2) unjuk kerja media pembelajaran berjalan baik, dengan 71 fitur dari 72 fitur berfungsi sesuai dengan harapan. Satu fungsi minor belum dapat disempurnakan karena keterbatasan kemampuan pemrograman peneliti; dan (3) kelayakan media pembelajaran mendapat penilaian Sangat Layak (93,04\%) dari Ahli Materi I, Layak $(72,17 \%)$ dari Ahli Materi II, Sangat Layak $(86,65 \%)$ dari Ahli Media I, Sangat Layak $(89,29 \%)$ dari Ahli Media II, Layak (78,52\%) dari pengguna. Meskipun media dinyatakan layak dari tiga aspek uji, akan tetapi ditemukan bahwa genre RPG dinilai kurang tepat dikarenakan siswa terkecoh dengan sistem permainan yang memerlukan waktu pemahaman yang lama. Penggunaan RPG sebagai pendekatan pada media pembelajaran untuk materi teknik perlu dikaji lebih mendalam. Pendekatan RPG pada media pembelajaran diharapkan tidak menimbulkan permasalahan baru dalam proses pemahaman siswa.

\section{DAFTAR PUSTAKA}

[1] J. Choppin, A. McDuffie, C. Drake, and J. Davis, "Curriculum ergonomics: Conceptualizing the interactions between curriculum design and use," Int. J. Educ. Res., vol. 92, pp. 75-85, 2018.

[2] A. Munib, Budiono, and S. Suryono, Pengantar ilmu pendidikan, 6th ed. Semarang: Universitas Negeri Semarang, 2009. 
[3] Y. Udjaja, Renaldi, Steven, K. Tanuwijaya, and I. K. Wairooy, "The Use of Role Playing Game for Japanese Language Learning," Procedia Comput. Sci., vol. 157, pp. 298-305, 2019.

[4] M. Vinogradova and N. Ivanova, "Pedagogical Conditions for Role-Playing Game Development in Senior Preschool Age Children," Procedia Soc. Behav. Sci., vol. 233, pp. 297-301, 2016.

[5] A. Shafie and W. F. W. Ahmad, "Design and Heuristic Evaluation of MathQuest: A RolePlaying Game for Numbers," Procedia - Soc. Behav. Sci., vol. 8, pp. 620-625, 2010.

[6] G. P. Cikarge and P. Utami, "Analisis dan Desain Media PEmbelajaran Praktik Teknik Digital sesuai RPS," ELINVO(Electronics, Informatics, Vocat. Educ., vol. 3, no. 1, pp. 92-105, 2018.

[7] Sugiyono, Metode Penelitian Kuantitatif Kualitataif dan Kombinasi (Mixed Methods). Bandung: Alfabeta, 2016.

[8] R. S. Wahono, "Media pembelajaran dalam aspek rekayasa perangkat lunak," romisatriawahono.net lecture note in software engineering, computing research and technopreneurship, 2006. [Online]. Available: https://romisatriawahono.net/2006/06/23/mediapembelajaran-dalam-aspek-rekayasa-perangkatlunak/.

[9] F. Reer and N. C.Krämer, "Are online roleplaying games more social than multiplayer firstperson shooters? Investigating how online gamers' motivations and playing habits are related to social capital acquisition and social support," Entertain. Comput., vol. 29, pp. 1-9, 2019. 